\title{
THE MONITORING OF CARBON MONOXIDE AIR POLLUTANT, AS PART OF THE AIR QUALITY MANAGEMENT. CASE STUDY: THE OLT COUNTY, ROMANIA
}

\author{
Dana-Maria (Oprea) Constantin ${ }^{1}$ \\ Dan Ioan Topor ${ }^{2}$ \\ Sorinel Căpuşneanu ${ }^{3}$ \\ Cristian-Marian Barbu ${ }^{4}$ \\ Elena Bogan ${ }^{5}$
}

\begin{abstract}
The processes that cause changes to the natural characteristics of the air have a strong dynamic; this being a reason why the environmental study must have sufficient quantitive and qualitative data, in order to meet the appropriate requirements of the spatial and temporal representation. This paper deals with issues of the air quality management in the Olt County, for the pollution indicator - carbon monoxide $(\mathrm{CO})$. The paper presents the main features of this pollutant, the emission sources and the monitoring for 2014, the year with the lowest emission of CO, for the period 2008 - 2014, in terms of the annual, monthly and daily average concentrations, in relation to the causes that diminish or emphasize the values. In the end of the paper, the authors present the conclusions based on the data interpretations, provided after the monitoring of the pollution indicator - $\mathrm{CO}$.
\end{abstract}

Keywords: Pollution, ambient air, carbon monoxide, environment management, monitoring, the Olt County

JEL Codes: Q50, Q52, Q57

\section{Introduction}

The awareness of the air pollution consequences at local, regional and global scale is relatively recent, after 1970, both in the United States of America and in Europe so that the managers began to realize that they have not only a economic responsibility, but also a social and organic one for the natural environment in which they operate and whose resources are used (Dumitriu, 2003).

The environmental protection, welfare and social justice have become priorities, the social solutions which involve the local communities, complementing the technological ones (Stehr and von Storch, 2015). The anthropogenic climate change is the current global problem, which is explained by releasing the polluting gases into the atmosphere. The air pollution means the change of the composition in terms of the proportion of its constituents and/or the emergence of new constituents, with harmful effects on the environment (Penescu et al., 2001). The gas and vapors pollution is greater and stronger in diversity than the dust pollution (Oprea, 2013).

The air quality management has two main components: the assessment and the surveillance (monitoring) the air quality and emissions, plus the control of the pollution sources (Duţu, 2010).

\footnotetext{
${ }^{1}$ University of Bucharest, Faculty of Geography, Email: danamartines @ yahoo.com

21 Decembrie 1918 University, Alba-Iulia, Email: dan.topor@yahoo.com

${ }^{3}$ Dimitrie Cantemir Christian University, Bucharest, Email: sorinelcapusneanu@ gmail.com

${ }^{4}$ Artifex University, Bucharest, Email: doctrine.economice@ gmail.com

${ }^{5}$ University of Bucharest, Faculty of Geography, Email: elena.bogan@yahoo.com
} 
At global level, the United Nations Environment Program - UNEP has conducted a comprehensive program of environmental monitoring, consisting of:

- The Global Environmental Monitoring System - GEMS, operational in 142 countries;

- $\quad$ The Integrated Global Fund Monitoring - IGBM;

- $\quad$ The INFOTERRA Data System, with data network in 140 de countries;

- The International Register of Potentially Toxic Chemicals - IRPTC (Ionac and Ciulache, 2005).

At national level, the National Network for Monitoring Air Quality is involved in the air quality assessment and management (NEPA, 2015), being integrated in the global network GEMS, plus the National System for the Air Pollutants Emission Inventory.

This article will analyze and interpreted the data for the air pollution indicator - carbon monoxide (CO), in the Olt County, for 2014, the data being provided by the Air Quality Monitoring System operated by the Environmental Protection Agency of the Olt County. 2014 is the year in which it was registered the lowest annual average concentration, for the period $2008-2015$. The analysis of the pollution indicator - carbon monoxide, is motivated by the fact that, the carbon compounds tops in quantity of the polluting gases, although the concentrations of carbon monoxide decreased by about a third in the EU, in the last decade (European Environment Agency, 2015) and because the Olt County is well represented by the aluminum industry - the only producer of primary aluminum in the country and the largest in the Eastern Europe (Constantin, 2013).

\section{Materials and methods}

The carbon monoxide, under natural conditions, is found in small amounts in the air, between $0.05-0.2$ ppmv (parts per million by volume), (Heidt et. al, 1980). In the atmosphere of the human settlements, the presence of the pollutant - carbon monoxide is caused by incomplete combustion, being, from this point of view, the most widespread and most common component of the air pollution (Rădulescu, 2008). The carbon monoxide does not come only from the power plants; industrial or residential open burning, but also from the car traffic (Lau et. al, 2009).

The carbon monoxide is a toxic gas, tasteless, odorless, colorless and with a lower density than air $\left(1.25 \mathrm{~kg} / \mathrm{Nm}^{3}\right)$, which makes to be easily moved by air currents in a room. From chemical point of view, it is very stable, having a preservation time in atmosphere of 1-5 years (Popescu and Popescu, 2000). follows:

Industrial, $\mathrm{CO}$ is obtained from the natural gas or coal conversion in gas mixtures, as it

- $2 \mathrm{C}+\mathrm{O}_{2} \rightarrow 2 \mathrm{CO}-$ gas air;

- $\mathrm{C}+\mathrm{H}_{2} \mathrm{O} \leftrightarrow \mathrm{CO}+\mathrm{H}_{2}$ - water gas, la $1200{ }^{\circ} \mathrm{C}$;

- $\mathrm{CH}_{4}+\mathrm{H}_{2} \mathrm{O} \rightarrow \mathrm{CO}+3 \mathrm{H}_{2}-$ synthesis gas, at $850{ }^{\circ} \mathrm{C}$, in the presence of Nickel - based catalysts (Rădulescu, 2008).

In analyzing the $\mathrm{CO}$ pollution indicator, in terms of monitoring and control of emissions, as part of the air quality management, there have been used the yearly, monthly and daily average data provided by the Environmental Protection Agency of the Olt County (APM Olt, 2014).

The monitoring of the $\mathrm{CO}$ pollutant in the Olt County is achieved by the automatic industrial-type station for air quality monitoring (OT-1 station) located in Slatina, which is part of the national network of air quality monitoring. The data provided by this station are representative for an area between 100 and $1000 \mathrm{~m}$.

The data on concentrations of $\mathrm{CO}$ from the automatic industrial-type station are complemented by systematic measurements which are performed using the monitoring network composed of fixed sampling points per 24 hours at the Slatina industrial platform, the mobile stations located in the main intersections and the laboratories for analysis and the evaluation of the key economic industrial pollutants that constitute the major sources of pollution. The major sources of pollution in the Olt County are: SC ALRO SA, SC ALTUR SA, SC TMK ARTROM, SC 
ELECTROCARBON SA, SC PIRELLI TYRES, located in Slatina; SC SMR SA - Balş; SC IGO SA - Caracal and SC BIOMOTOR SRL - Deveselu.

Besides of the environmental data, there were used statistical methods, graphics and mapping, as well as the facilities of the Microsoft Office software package.

The interpretation of the data from the physical-chemical analyzes is done according to STAS $12574 / 1987$ and MAPPM Order 592/2002 on air quality conditions in protected areas (APM Olt, 2014). As a result, the maximum permitted concentration (MPC) for carbon monoxide is 10.0 $\mathrm{mg} / \mathrm{m}^{3}$ for 8 hours.

\section{Results and discussions}

The study area used in the analysis of the data for the pollution indicator - $\mathrm{CO}$, after the monitoring of the air quality, is the Olt County area. The Olt County ranks the $14^{\text {th }}$ largest in Romania (by surface), representing $2.3 \%$ of the country. It is located in the south, along the lower river which gave its name and it takes part of the counties bordering the Danube River (Figure 1).

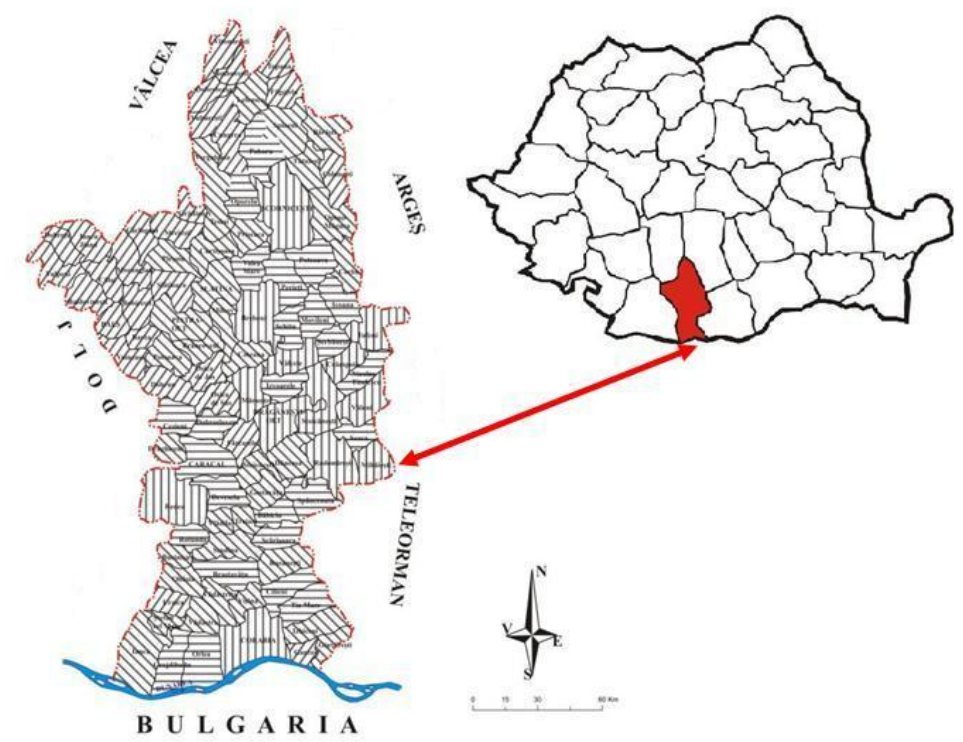

Figure 1. The study area

Source: Processed GIS open source, 2016

The analysis of the ambient air quality and pollution is carried out for the year 2014. The annual average concentration of CO in the ambient air in 2014 was $0.13 \mathrm{mg} / \mathrm{m}^{3}$, far below the maximum permitted concentration. In the same year, there were inventoried $\mathrm{CO}$ emissions in an amount of 162,583 tonnes. 2014 is the year with the lowest average annual concentration of CO, for the period 2008 - 2014, as shown in Figure 2. This aspect is the consequence of environmental investments made by major companies, during time, to improve environmental performance.

The monthly average concentration of $\mathrm{CO}$ pollutant allows the highlighting of the annual monthly average regime, characterizing the average level of air contamination in every month of the year, and the deviations from the maximum permissible concentration. These monthly averages of the $\mathrm{CO}$ pollutant concentration are shown in Figure 3, being noticed higher monthly amounts in the cold season of the year, due to the emergence of new sources of $\mathrm{CO}$ pollution - the residential installations like stoves and individual heating plants. The highest monthly average concentration of CO pollutant is registered in December, from $0.31 \mathrm{mg} / \mathrm{m}^{3}$, followed in November by $0.18 \mathrm{mg} / \mathrm{m}^{3}$. The distribution of CO, during 2014, is also conditioned by the weather. In no month of the year 2014 was exceeded the maximum permitted concentration in 8 hours, of $10 \mathrm{mg} / \mathrm{m}^{3}$, as shown in the Table 1. 


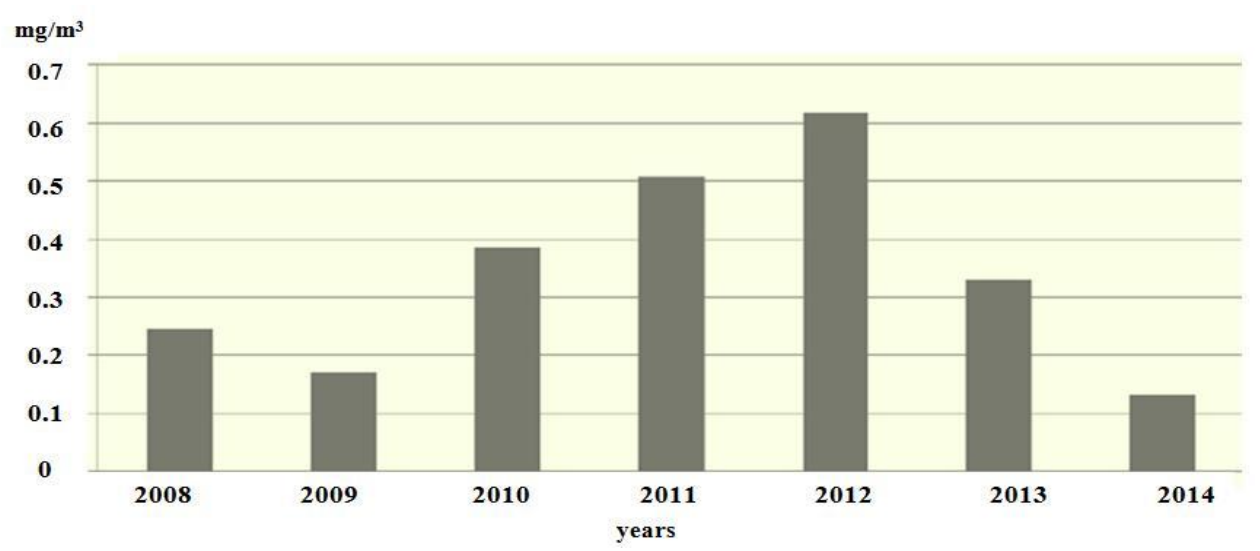

Figure 2. The evolution of the annual average values $(\mathrm{mg} / \mathrm{m3})$ of the $\mathrm{CO}$ indicator, in the Olt County for the period $2008-2014$

Source: Processed data after APM Olt - station OT-1, 2016

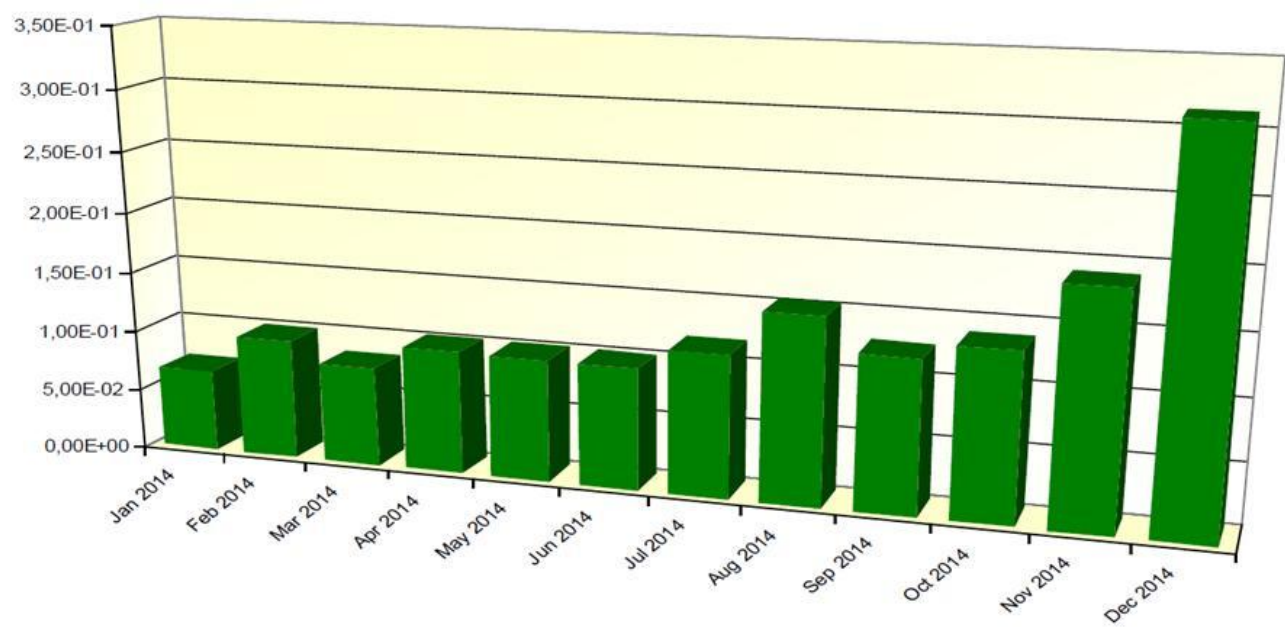

Figure 3. The monthly average values $\left(\mathrm{mg} / \mathrm{m}^{3}\right)$ of the $\mathrm{CO}$ indicator in the Olt County, for the year 2014

Sourse: Processed data after APM Olt - station OT-1, 2014

Table 1

The annual regime of the pollution indicator - CO, in the Olt County, for the year 2014

\begin{tabular}{|c|c|c|c|c|c|c|c|c|c|c|c|c|}
\hline month & & I & II & V & & I & II & III & $\mathbf{X}$ & & I & II \\
\hline $\begin{array}{r}\text { monthly } \\
\text { average }\left(\mathrm{mg} / \mathrm{m}^{3}\right)\end{array}$ & .06 & .09 & .08 & .1 & .01 & .09 & .11 & .15 & .12 & .13 & .18 & .31 \\
\hline $\operatorname{MPC}\left(\mathrm{mg} / \mathrm{m}^{3}\right)$ & 0 & 0 & 0 & 0 & 0 & 0 & 0 & 0 & 0 & 0 & 0 & 0 \\
\hline $\begin{array}{l}\text { monthly data } \\
\text { capture }(\%)\end{array}$ & 6.2 & 00 & 9.7 & 00 & 00 & 3.8 & 1.1 & 2.3 & 8.4 & 00 & 8.8 & 2.7 \\
\hline
\end{tabular}

Sourse: Processed data after APM Olt - station OT-1, 2016

Based on the graphics evolving the daily evolution of the period from September to December, corresponding the intensification of incomplete combustion of any type of combustible material from power plants, industrial, residential, outdoor installations (the incineration of stubble, wastes etc.) and traffic, plus the daily evolution of various processes and meteorological phenomena that can weaken or strengthen the concentrations of carbon monoxide, there will be explained, to a large extent, the higher concentrations of $\mathrm{CO}$ recorded in the morning and during the evening, with 
the resumption of productive activity, of the increased circulation and the lack or weak development of the thermal convection upward (Figures 4, 5, 6 and 7).

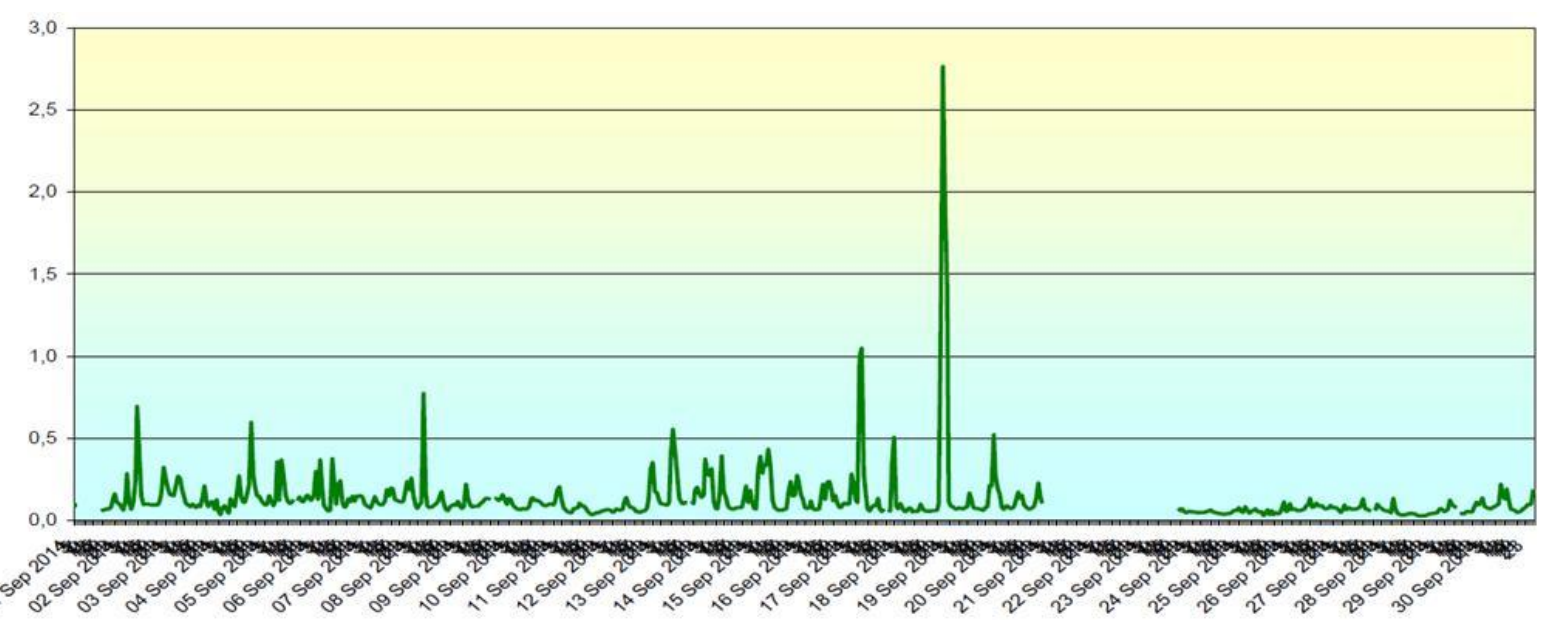

Figure 4. The daily average evolution $\left(\mathrm{mg} / \mathrm{m}^{3}\right)$ of the $\mathrm{CO}$ indicator in the Olt County, for September 2014

Sourse: After APM Olt - station OT-1, 2014

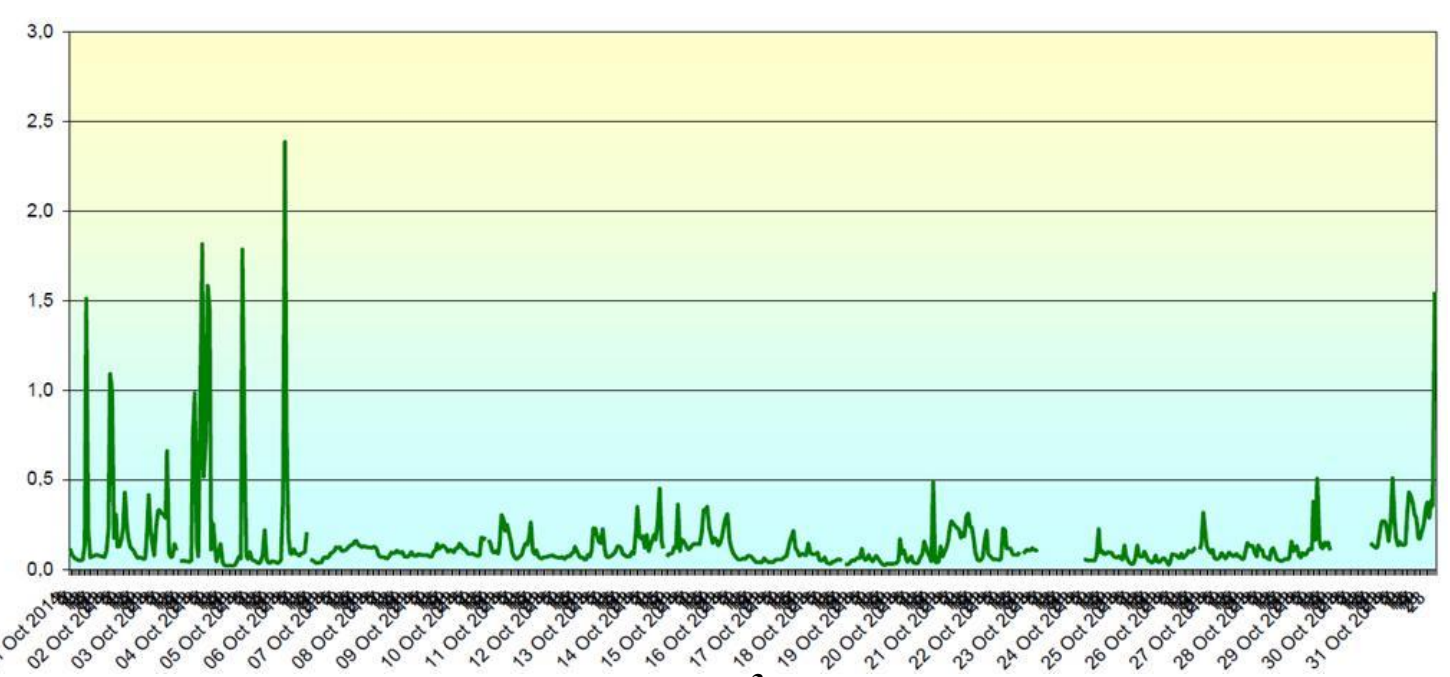

Figure 5. The daily average evolution $\left(\mathrm{mg} / \mathrm{m}^{3}\right)$ of the $\mathrm{CO}$ indicator in the Olt County, for October 2014

Sourse: After APM Olt - station OT-1, 2014 


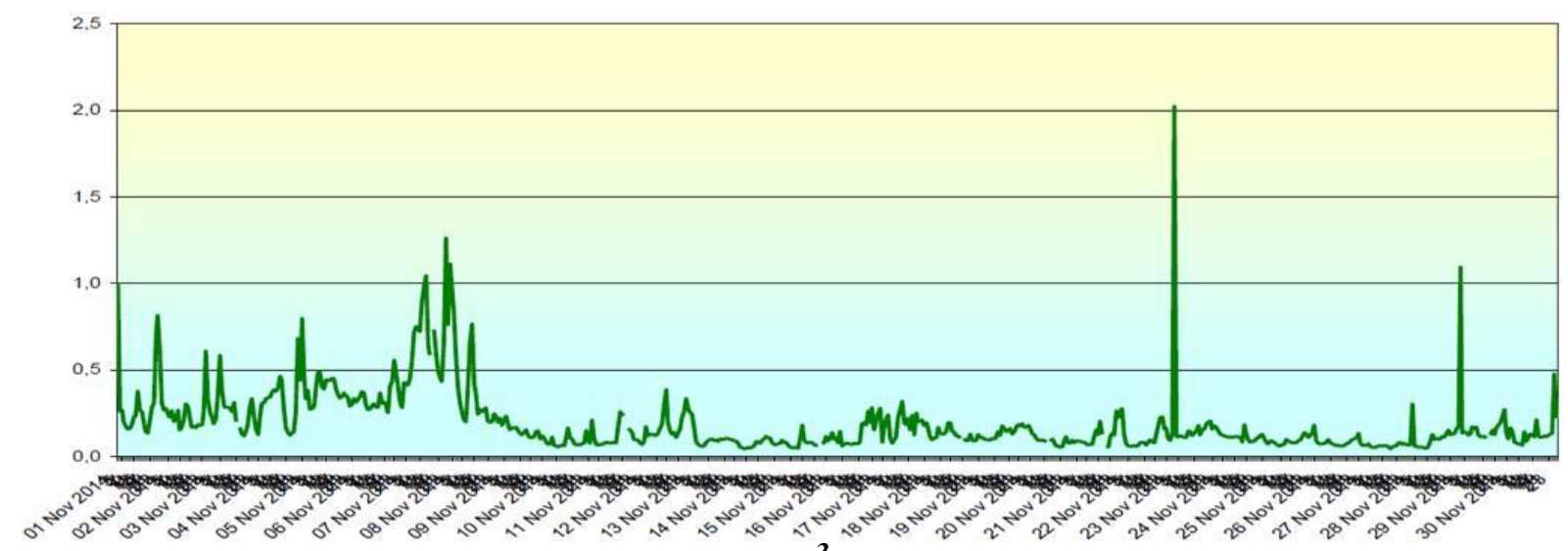

Figure 6. The daily average evolution $\left(\mathrm{mg} / \mathrm{m}^{3}\right)$ of the CO indicator in the Olt County, for November 2014

Sourse: After APM Olt - station OT-1, 2014

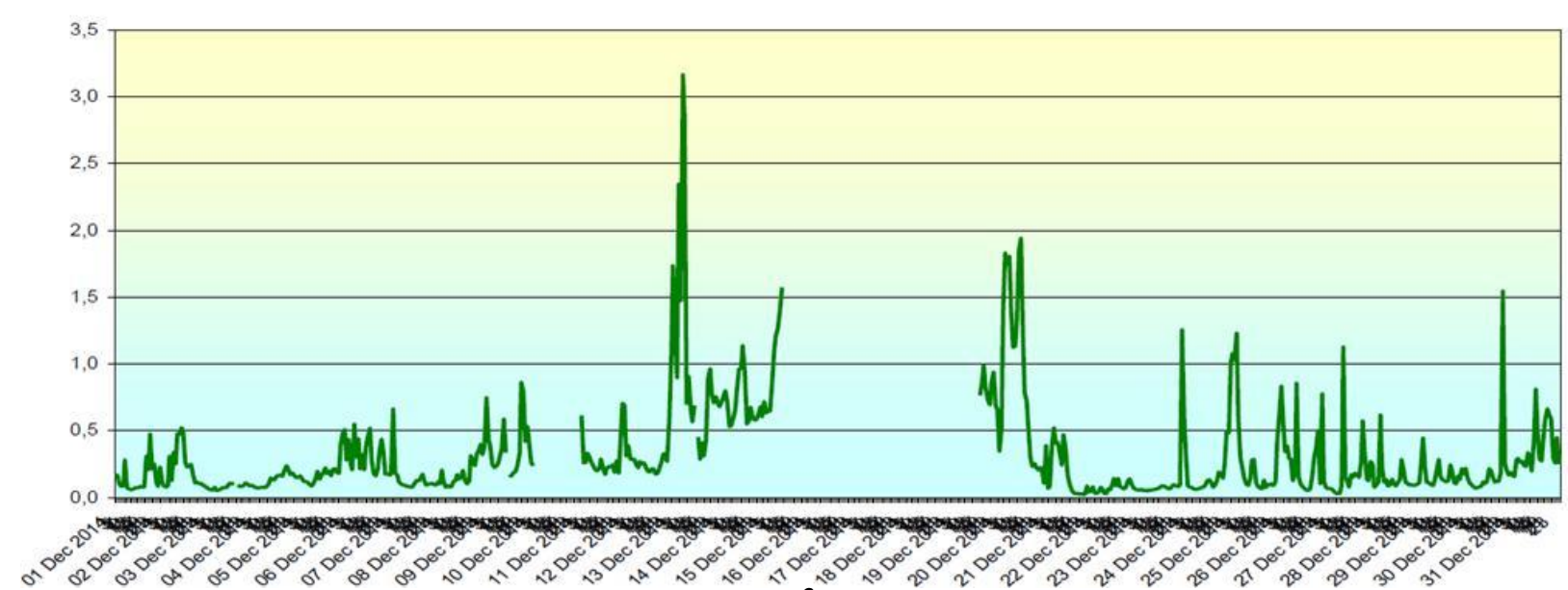

Figure 7. The daily average evolution $\left(\mathrm{mg} / \mathrm{m}^{3}\right)$ of the $\mathrm{CO}$ indicator in the Olt County, for December 2014

Sourse: After APM Olt - station OT-1, 2014

It can be noticed, from the daily evolution graphics for the period September - December, that the maximum admissible concentration of $10 \mathrm{mg} / \mathrm{m} 3$ has not exceeded, and the values were far below this value. Also, there is a disruption of the monthly regimes of the pollution indicator $\mathrm{CO}$, caused by the lack of data catch of the industrial-type automatic station OT-1, as shown in the Table 1.

\section{Conclusions}

The environmental monitoring constitutes the supervisory, forecasting, warning and intervention activity for the evaluation of the quantitative and qualitative features of the environmental factors, being a tool for an objective evaluation, ensuring an efficient management of the air quality and providing the necessary information for the environmental policy. Rethinking the urban settlements, promoting a sustainable urban transport, enabling a lower power consumption per capita, thermic rehabilitation of the buildings, the use of environmental technology performance, environmental education are viable and concrete solutions for the improvement of the environmental quality, for the reduction of the actual climate change effects, which will be reflected in improving the quality of the human life.

The carbon monoxide is the most common atmospheric pollutant, but it has a synergistic and asphyxiation action. The carbon monoxide reacts with hemoglobin to form carboxyhemoglobin, 
reducing the ability produce oxygen in the tissues of the body. The urban population has 1-2\% carboxyhemoglobin in the blood, due to the urban air pollution. The carbon monoxide in small doses causes headache, sensory disturbances and whirls.

The quantitative and qualitative analysis of a pollution indicator is the beginning phase in order to ensure the air quality management for a defined area, as part of the environmental management. In this case, the analysis was performed for the carbon monoxide indicator, for the year 2014, for the Olt County area. The daily, monthly and annually averages recorded are much lower than the maximum permitted concentration, following the EU directive to lower the concentrations of the air pollutants in order to ensure a good quality of the ambient air, in terms of a sustainable development. It also ensures and implements the provisions of Law no. 104/2011 on ambient air quality at local level (APM Olt, 2014).

\section{References}

1. *** Agenţia Naţională pentru Protecţia Mediului, 2015. Raportul anual privind starea mediului în România, anul 2014, http://www.anpm.ro/web/guest/acasa.

2. *** Agenţia pentru Protecţia Mediului Olt, 2015. Raportul privind starea mediului anul 2014 Judeţul Olt, http://www.anpm.ro/web/apm-olt/acasa.

3. *** Europen Environment Agency, 2015. Air quality in Europe - 2014 and 2015 reports, http://www.eea.europa.eu/.

4. Constantin (Oprea) D. M., 2013. Relaţia climă - poluarea mediului înconjurător în arealul municipiului Slatina, Editura Universitară, Bucureşti.

5. Dumitriu C., 2003. Management şi marketing ecologic. O abordare strategică, Editura Tehnopress, Iaşi.

6. Duţu M., 2010. Dreptul mediului - ediţia 3, Editura C.H. Beck, Bucureşti.

7. Heidt L.E., Krasneck J.P., Lueb R.A., Pollock W.H., Henry B.E., Crutzen P.J., 1980. Latitudinal distribution of $\mathrm{CO}$ and $\mathrm{CH}_{4}$ over the Pacific, Journal of Geophysical Research: Oceans, Volume 85, Issue C12, pp. 7329-7336.

8. Ionac N., Ciulache S., 2005. Ghid de cercetare environmentală, Editura Ars Docendi, Bucureşti.

9. Lau J.C., Huang W.T., Zuen D., Zuen D.D., Cheung C.S., 2009. Long-memory characteristics of urban roadside air quality, Transportation research part D: Transport and Environment, Volume 14, Issue 5, pp. 353-359.

10. Oprea D. M., 2013. The distribution over time and space of sulfur dioxide and influence on organic farming. Case study: the area of Slatina City, Scientific Papers Series „Management, Economic Engineering in Agriculture and Rural Development”, Volume 13, Issue 1, pp. 263-268.

11. Penescu A., Băbeanu Narcisa, Marin D.I., 2001. Ecologie şi protecţia mediului, Editura Sylvi, Bucureşti.

12. Popescu M., Popescu M., 2000. Ecologie aplicată, Editura Matrix Rom, Bucureşti.

13. Rădulescu C., 2008. Emisii poluante. Metode pentru reducerea acestora, Editura Bibliotheca, Târgovişte.

14. Stehr N., Hans von Storch, 2015. Clima şi societatea, Editura Ars Docendi, Bucureşti. 